\title{
Pengaruh Kepemimpinan Kepala Sekolah dan Manajemen Kepala Sekolah terhadap Kinerja Guru
}

\author{
Jaliah ${ }^{\bowtie 1}$, Happy Fitria ${ }^{2}$, Alfroki Martha ${ }^{3}$ \\ (1) Sekolah Menengah Pertama Muhammadiyah Prabumulih \\ $(2,3)$ Universitas PGRI Palembang
}

$\triangle$ Corresponding author

[Jaliahrahman92@gmail.com]

\begin{abstract}
Abstrak
Penelitian ini bertujuan untuk mengkaji pengaruh kepemimpinan kepala sekolah dan manajemen kepala sekolah terhadap kinerja guru. Penelitian ini menggunakan metode kuantitatif dengan jenis penelitian korelasional. Populasi penelitian ini sebanyak 99 orang guru PNS dari SMP negeri 7 Prabumulih, SMP negeri 8 Prabumulih, dan SMP negeri 12 Prabumulih. Teknik pengumpulan data menggunakan angket. Data dianalisis menggunakan teknik analisis korelasi dan regresi ganda. Hasil penelitian menunjukkan bahwa (1) kepemimpinan kepala sekolah berpengaruh positif dan signifikan terhadap kinerja guru, (2) manajemen kepala sekolah mempunyai pengaruh terhadap kinerja guru, (3) motivasi kerja dan manajemen kepala sekolah mempunyai pengaruh yang positif dan signifikan terhadap kinerja guru di SMP Negeri Prabumulih.
\end{abstract}

Kata Kunci: Kepemimpinan Kepala Sekolah; Manajemen Kepala Sekolah; Kinerja Guru.

\begin{abstract}
This study aims to examine the influence of principal leadership and principal management on teacher performance. This research uses quantitative methods with correlational research type. The population of this study was 99 civil servants who were spread across SMP Negeri 7 Prabumulih, SMP Negeri 8 Prabumulih, and SMP Negeri 12 Prabumulih. The data collection technique used a questionnaire. Data were analyzed using correlation analysis techniques and multiple regression. The results showed that (1) principal leadership had a positive and significant effect on teacher performance, (2) principal management had an influence on teacher performance, (3) work motivation and principal management had a positive and significant effect on teacher performance in SMP Negeri Prabumulih.
\end{abstract}

Keyword: Principal Leadership; Principal Leadership; Teacher Performance.

\section{PENDAHULUAN}

Sekolah merupakan suatu lembaga pendidikan atau tempat berlangsungnya proses pendidikan seperti mengajar, mendidik, membimbing, mengarahkan yang mana didalamnya terdapat unsur-unsur manajerial yang selalu mengelola, mengorganisir, merencanakan dan mengawasi segala apa yang terjadi di lembaga tersebut. Agar pelaksanaan pendidikan dapat berjalan dengan baik dan mencapai tujuan yang telah ditetapkan, semua komponen dalam system manajerial dalam lembagapendidikan formal tentunya dilaksanakan oleh kepala sekolah sebagai pemegang pimpinan di lembaga tersebut sehingga sudah sepantasnya peran-peran manajerial dilaksanakan oleh kepala sekolah sebagai pucuk pimpinan tertinggi, maka kepemimpian kepala sekolah sangat menentukan berhasil tidaknya lembaga yang ia pimpin karena kepala sekolah merupakan motor penggerak bagi para bawahannya yakni para dewan guru di sekolah beserta staf tata usaha.

Seiring dengan perkembangan pendidikan di Indonesia dengan diberlakukannya Undang-Undang Nomor 22 Tahun 1999 tentang Pelaksanaan Pemerintah Daerah membawa konsekuensi logis pada perubahan paradigma pengelolaan pendidikan dari yang bersifat sentralistis menjadi desentralitis. Perubahan ini, pada satu sisi menguntungkan sebab pendidikan di sekolah dapat dilaksanakan secara lebih leluasa dan mandiri sesuai dengan kemampuan masing-masing sekolah, namun pada sisi lain akan menjadi kendala pada pelaksanaannya apabila kesiapan sekolah tidak sejalan dengan tuntutan dari kebijakan undang undang tersebut. Salah satu upaya pemerintah untuk mendukung pelaksanaan undang undang tersebut adalah dengan meningkatkan kualifikasi pendidikan guru melalui program penyetaraan. Guru-guru Sekolah Dasar (SD), minimal harus berlatar belakang (DII), guru-guru SLTP minimal harus berlatar belakang (DIII), sedangkan guru-guru SLTA minimal harus berlatar belakang (S1).Upaya-upaya tersebut masih dilengkapi dengan berbagai pelatihan dan penataran serta sertifikasi guru yang pelaksanaannya akan dimulai tahun ini. 
Usaha tersebut mengindikasikan masih perlu ditingkatkannya kinerja guru. Kinerja guru dapat dilihat dari proses kerja atau hasil kerja. Suatu pekerjaan selalu mempunyai langkah-langkah (prosedur) kerja, prosedur kerja selalu mengarah pada peningkatan hasil pekerjaan yang sesuai dengan tuntutan kerja. Apabila suatu pekerjaan dilakukan sesuai dengan prosedurnya, maka akan sampai pada hasil kerja yang diinginkan. Tolok ukur dari kinerja adalah tuntutan pekerjaan yang menggambarkan hasil kerja yang ingin dicapai. Seberapa jauh seseorang mampu melakukan pekerjaan kemudian dibandingkan dengan hasil yang dicapai dinamakan Karena demikian pentingnya faktor kinerja guru dalam peranannya untuk meningkatkan keberhasilan pendidikan, maka menjaga dan mengupayakan agar guru memiliki kinerja yang tinggi mutlak diperlukan. Faktor-faktor apa yang berpengaruh terhadap peningkatan kinerja guru perlu segera dicari jawabannya agar masalah peningkatan mutu pendidikan, khususnya SMP Negeri di Prabumulih segera dapat terwujud.

Guru merupakan kunci utama untuk meningkatkan kualitas pendidikan, karena persyaratan penting bagi terwujudnya pendidikan yang bermutu adalah apabila pelaksanaannya dilakukan oleh pendidik-pendidik yang keprofesionalannya dapat diandalkan. Menurut Slamet dunia pendidikan tidak akan mengalami perubahan apapun sepanjang para dosen dan guru tidak mau berubah, tidak adaptif dan antisipatif terhadap perubahan. Indikator-indikator penting mengenai kondisi pendidikan kita saat ini satu diantaranya adalah masih rendahnya kualitas guru untuk semua jenjang pendidikan (Wachidi dkk, 2019; Riyanto dkk, 2019; Badeni, 2019; Mukartik dkk, 2020; Zulaiha dkk, 2020; Komalasari dkk, 2020; Rohma dkk, 2020; Abdullah, 2020).

Dalam pelaksanaannya menuntut perubahan sikap dan tingkah laku dari seluruh komponen sekolah, baik kepala sekolah, guru dan staf administrasi, termasukorangtua dan masyarakat dalam memandang, memahami dan membantu sekaligus sebagai pemantau yang melaksanakan monitoring dan evaluasi dalam pelaksanaan sekolah. Perubahan sikap dan tingkah laku tersebut akan dapat terjadi bila sumberdaya sekolah yang ada dimanfaatkan dan dikelola secara optimal dan efektif oleh kepala sekolah selaku orang yang bertanggung jawab dalam pelaksanaan pendidikan di sekolah.

Menurut Brotosedjati (2002) Tuntutan akan kepala sekolah yang memiliki kemampuan manajemen dan kepemimpinan yang tangguh tersebut pada kenyataannya tidak terlepas dari isu-isu praksis pendidikan maupun isu-isu yang berkaitan dengan desentralisasi pendidikan, yakni: Isu-isu yang sering muncul tersebut antara lain; keterbatasan wewenang kepala sekolah yang berimplikasi pada rendahnya efektivitas pencapaian target pendidikan disekolah. Isu ini menyangkut pula minimnya kewenangan yang diberikan kepada kepala sekolah dalam mengembangkan manajemen pendidikan disekolah termasuk keterbatasan ruang geraknya dalam memanfaatkan sumber-sumber pendidikan yang dialokasikan pada sekolah.

Dalam persoalan kemandirian dan kreativitas pengelolaan pendidikan disekolah sangat tergantung kepada keandalan seorang kepala sekolah, dimana kepala sekolah memiliki kewenangan yang lebih besar untuk mengambil keputusan yang berkaitan dengan kebijakan pengelolaan sekolah dibandingkan dengan sistem manajemen pendidikan yang dikelola oleh pemerintah pusat. Sedangkan dalam hal keterbukaan, akuntabilitas manajemen sekolah, maka kepala sekolah selaku manajer dalam mengatur dan mengurus sekolahnya hendaknya memperhatikan input-input manajemen sekolah.

Menurut Mulyasa (2007) Untuk itu dalam pelaksanaanya kepala sekolah diharapkan menerapkan prinsip efesiensi, efektivitas, produktivitas dan inovasi dalam pengelolaan pendidikan. Menyadari betapa penting peningkatan mutu sekolah yang dapat dilihat dari indikator; mutu masukan, mutu proses, mutu SDM, mutu fasilitas, mutu manajemen, dan beaya, maka perlu mendukung kemampuan manajerial kepala sekolah guna meningkatkan mutu pendidikan disekolah tersebut.

Dengan demikian kepala sekolah hendaknya dapat menjalankan fungsi dan tugas dengan sebaikbaiknya serta memainkan peran yang sesuai, yakni sebagai pemimpin sekaligus sebagai manajer. Disamping itu sekolah sebagai agen perubahan, maka kepala sekolah harus memahami dan mengembangkan ketrampilannya dalam melaksanakan perubahan itu, apabila kepala sekolah ingin sekolah yang dipimpinnya menjadi lebih efektif.

Dengan demikian bahwa hubungan antara mutu kepemimpinan kepala sekolah berkaitan erat dengan peningkatan berbagai aspek kehidupan sekolah, seperti predikat sekolah yang mutunya baik dan mutunya kurang baik banyak berkaitan erat dengan mutu kepemimpinan dan manajemen kepala sekolah, sebagai orang yang bertanggung jawab dalam pengelolaan pendidikan di sekolah. Salah satu aspek utama yang berkaitan erat dengan kinerja kepala sekolah adalah dilihat dari tingkat keberhasilan kepemimpinan dan manajemen kepala sekolah pengaruhnya terhadap peningkatan kinerja guru dan karyawan yang turut serta meningkatkan prestasi siswa menuju peningkatan mutu berdasarkan visi dan misi sekolah yang telah disepakati bersama.

Kinerja menurut Drucker (Yahya, 2013) adalah tingkat prestasi atau hasil nyata yang dicapai dipergunakan untuk memperoleh suatu hasil positif. Menurut Whitmore (Hamzah dan NinaLamatenggo, 2012) mengemukakan kinerja adalah "pelaksanaan fungsi-fungsi yang dituntut dari seseorang". Kinerja merupakan hasil kerja yang dicapai seseorang dalam melaksanakan tugas-tugas yang dibebankan kepadanya didasarkan atas kecakapan, pengalaman, kesungguhan dan waktu (Hasibuan, 1997). Lebih lanjut, Hasibuan 
menggungkapkan bahwa kinerja merupakan gabungan tiga faktor penting yaitu kemampuan dan minat seorang pekerja, kemampuan serta penerimaan atas penjelasan delegasi tugas dan peran serta pekerja.

Kinerja guru pada dasarnya merupakan kinerja atau unjuk kerja yang dilakukan oleh seorang guru dalam melaksanakan tugasnya sebagai seorang pendidik. Kualitas seorang guru akan sangat menentukan hasil dari pendidikan, karena guru merupakan pihak yang berhubungan langsung dengan peserta didik dalam proses pendidikan atau pembelajaran di lembaga pendidikan sekolah.

Banyak faktor yang mempengaruhi kinerja dari seseorang, menurut Sumarno (2009) menyebutkan ada 3 faktor yang mempengaruhi kinerja, yaitu kemampuan, kepribadian dan minat kerja. Kemampuan merupakan kecakapan seseorang, seperti kecerdasan dan ketrampilan. Kemampuan pekerja dapat mempengaruhi kinerja dalam berbagai cara. Misalnya dalam cara pengambilan keputusan, cara menginterprestasikan tugas dan cara penyelesaian tugas. Kepribadian adalah serangkaian ciri yang relatif mantap yang dipengaruhi oleh keturunan dan factor sosial, kebudayaan dan lingkungan. Sedangkan minat merupakan suatu valensi atau sikap. Kejelasan dan penerimaan atas penjelasan peran seorang pekerja, yang merupakan taraf pengertian dan penerimaan seorang individu atas tugas yang dibebankan kepadanya. Makin jelas pengertian pekerja mengenai persyaratan dan sasaran pekerjaannya, maka makin banyak energi yang dapat dikerahkan untuk kegiatan kearah tujuan. Tingkat motivasi pekerja. Motivasi adalah daya energi yang mendorong, mengarahkan dan mempertahankan perilaku. Sehingga kinerja seseorang dapat lebih meningkat dengan adanya dorongan dari dalam dirinya yang dimiliki oleh seseorang tersebut sebagai modal dalam melaksanakan suatu pekerjaan.

Kemudian menurut keputusan bersama Menteri Negara Pendayagunaan Aparatur Negara dan Reformasi Birokrasi Nomor 16 Tahun 2009 tentang Jabatan Fungsional Guru dan angka kreditnya serta peraturan bersama Menteri Pendidikan Nasional dan Kepala Badan Kepegawaian Negara, Nomor 14 Tahun 2010 dan Nomor 03/V/PB/2010 tentang Petunjuk Pelaksanaan Jabatan Fungsional Guru dan angka kreditnya 1) guru adalah pendidik profesional dengan tugas utama mendidik, mengajar, membimbing, mengarahkan, melatih, menilai, dan mengevaluasi peserta didik pada pendidikan anak usia dini jalur pendidikan formal, pendidikan dasar, dan pendidikan menengah; 2) kegiatan pembelajaran adalah kegiatan guru dalam menyusun rencana pembelajaran, melaksanakan pembelajaran yang bermutu, menilai dan 3) mengevaluasi hasil pembelajaran, menyusun dan melaksanakan program perbaikan dan pengayaan terhadap peserta didik.Kegiatan bimbingan adalah kegiatan guru dalam menyusun rencana bimbingan, melaksanakan bimbingan, mengevaluasi proses dan hasil bimbingan, serta melakukan perbaikan tindak lanjut bimbingan dengan memanfaatkan hasil evaluasi.

Alam kinerja dapat dilihat dari evaluasi kinerja guru. Menurut Herlina (2018) pengertian penilaian pelaksanaan pekejaan yang bersifat komprehensip meliputi: 1) Penilaian kinerja adalah usaha mengidentifikasi, mengukur atau menilai, 2) Mengelola pelaksanaan pekerjaan oleh para guru/karyawan, 3) Penilaian kinerja adalah usaha mengidentifikasi dan menilai aspek-aspek pelaksanaan pekerjaan yang berpengaruh kepada kesuksesan organisasi non profit dalam mencapai tujuannya, 4) Penilaian prestasi kerja adalah kegiatan menilai untuk menetapkan seorang guru/karyawan sukses atau gagal dalam melaksanakan pekerjaannya dengan mempergunakan standar pekerjaan sebagai tolak ukumya. Menurut Herlina (2018) empat faktor kinerja pegawai sebagai standar penilaian kinerja yaitu: 1) kualitas kerja, 2) kuantitas kerja, 3) keandalan atau dapat tidaknya di andalkan, 4) sikap yang meliputi sikap pegawai lain.

Nurhayati (2012) kepemimpinan adalah kekuasaan untuk mempengaruhi seseorang untuk mengerjakan sesuatu. Untuk itu, kepemimpinan membutuhkan penggunaan kemampuan secara aktif untuk mempengaruhi pihak lain dalam mewujudkan tujuan organisasi yang diterapkan. Dalam arti luas seni untuk mempengaruhi perilaku manusia baik perseorangan maupun kelompok. Kepemimpinn dapat berlangsung tanpa harus terikat oleh aturan-aturan yang ada. Seorang pemimpin bertanggung jawab dalam pengambilan keputusan, pembuatan program kerja, pembuatan kontrak atau pembuatan aturan-aturan baru. Dalam konteks struktural kepemimpinan diartikan sebagai proses pemberian motivasi agar orang-orang yang dipimpin melakukan pekerjaan sesuai dengan program yang telah ditetapkan. Kepemimpinan juga berarti usaha mengarahkan, membimbing dan mempengaruhi orang lain agar pikiran dan kegiataan tidak menyimpan dari tugas pokok masing-masing. Adapun dalam konteks non struktural kepemimpinan dapat diartikan sebagai proses mempengaruhi pikiran, perasaan, tingkah laku, dan mengarahkan semua fasilitas untuk mencapai tujuan yang telah ditetapkan bersama.

Kepemimpinan juga merupakan beberapa karakteristik individu yang mendorong individu lain untuk mencapai tujuan sebagaimana menurut Berocci (2009) "Leadership is the combination of characteristics or personality traits in a individual that person to inspire others to achieve goals that, without leader's motivation would not normally be accomplihed". Selanjutnya ia mengungkapkan: "leadership effectiveness depend on the relationship among leaders, followers, and the circumstances involved. Keefektifan suatu kepemimpinan bergantung pada hubungan diantara sesama pemimpin, bawahan, berdasarkan uraian di atas ada beberapa hal berkaitan dengan kepemimpinan yaitu 1) mempengaruhi orang lain untuk mencapai tujuan organisasi; 2) memotivasi bawahan untuk mau melakukan pekerjaannya dengan baik; 3) mengartikulasikan visi dan nilai 
dengan baik; 4) mampu memobilisasi sumber daya yang ada untuk mencapai tujuan; 5) memberikan arah untuk mencapai tujuan organisasi.

Budianto dan Komalasari (2016) menjelaskan bahwa Kualitas kepempinan akan lebih memberikan daya pengaruh bila ditunjang oleh kecakapan, keterampilan, dan kemampuan dalam menangani bebagi hal. Pada umumnya, keberhasilan seorang pemimpin dalam menjalankan tugasnya dapat diukur dari produktivitas dan efektivitas pelaksanaan tugas-tugas yang dibebankan pada dirinya. Bila produktivitasnya naik dan semua tugas dilaksanakan dengan efektif maka ia disebut sebagai pemimpin yang berhasil. Sedang apabila produktivitasnya menurun dan kepemimpinnya tidak efektif dalam jangka waktu tertentu maka ia disebut sebagai pemipin yang gagal.

Menurut Mulyadi (2002) mengemukakan Kepemimpinan adalah dimensi hubungan sosial dalam organisasi dalam rangka memberikan pengaruh antar individu atau kelompok melalui interaksi sosial, mengidentifikasi kepemimpinan. Menurut Sagala (2009) menyatakan Kepemimpinan adalah hubungan antara seorang pemimpin dalam mempengaruhi orang lain untuk bekerja secara sadar dalam hubungan tugas untuk mencapai yang diinginkan pemimpin. Sedangkan Wirawan dalam Syaiful Sagala mengemukakan kepemimpinan adalah sebagai proses pemimpin menciptakan visi, mempengaruhi sikap, perilaku, pendapat, nilai-nilai, norma dan sebagainya dari pengikut untuk merealisasikan visi.

Menurut Robbins (2003) kepemimpinan adalah kemampuan untuk mempengaruhi sekelompok anggota agar bekerja mencapai tujuan dan sasaran. Sedangkan Kotter (2002) menyatakan Kepemimpinan adalah seperangkat proses yang terutamaditujukan untuk menciptakan organisasi atau menyesuaikannya terhadap keadaan-keadaan yang jauh berubah.

Kepemimpinan adalah kemampuan menggerakkan, memberikan motivasi dan mempengaruhi orangorang agar bersedia melakukan tindakan-tindakan yang terarah pada pencapaian tujuan melalui keberanian mengambil keputusan tentang kegiatan yang harus dilakukan. Definisi kepemimpinan dari Northouse (2013) adalah proses dimana individu mempengaruhi individu yang lain untuk mencapai tujuan bersama. Penempatan kepemimpinan sebagai proses berarti bukan sifat yang ada di dalam diri pemimpin dan pengikut. Proses menyatakan bahwa pemimipin mempengaruhi dan dipengaruhi oleh pengikut. Hal itu menekankan kepemimpinan itu tidak bersifat linear dan bukan peristiwa suatu arah, tetapi merupakan peristiwa yang interaktif. Hal tersebut di jelaskan juga oleh Sharma dan Jain (2013) bahwa kepemimpinan adalah proses dimana seseorang mempengaruhi orang lain untuk mencapai tujuan serta mengarahkan organisasi dengan cara yang kohesip dan koheran. Proses ini dilakukan dengan pengetahuan dan ketrampilan dari seorang pemimpin. Menurut mereka ada empat faktor kepemimpinan yaitu Leader seseorang yang mengenal diri sendiei mengenal apa yang dilakukannya supaya mempengaruhi anggotanya. Follower setiap anggota mempunyai kebutuhan yang berbeda maka dibutuhkan gaya kepemimpinan yang berbeda pula. Misalnya anggota kurang berpengalaman dalam kerja maka dibutuhkan pendekatan secara khusus dari pemimpin. Communication sebagai pemimpin, memimpin anggota melalui komunikasi dua arah. Sebagai besar bersfat nonverbal bahwa ketika pemimpin memberikan contoh komunikasi tidak dengan bertanya pada bawahan untuk melakukan apa yang diinginkan oleh pemimpin namun harus mendengarkan pendapat dari anggota. Situation dalam situasi yang tidak berhasil membutuhkan pemimpin yang mampu untuk memutuskan. Dalam hal ini pemimpin harus menggunakan gaya kepemimpinan untuk memutuskan tindakan yang terbaik untuk menyelesaikan.

Dalam kegiatan perencanaan, tugas kepala sekolah yang dijalankan adalah menyusun rencana program dan tujuan sekolah seperti menyususn kalender pendidikan, jadwal mengajar, dan lain-lain, menyusun kebijakan dan strategi serta prosedur pelaksanaan kegiatan, menyusun peraturan sekolah untuk mendukung pelaksanaan program sekolah, mengidentifikasi dan mempersiapkan sumber daya manusia, dan menyusun rencana anggaran sekolah (RAPBS).

Kegiatan ini menuntut kepala sekolah memperhatikan data dan fakta tentang kegagalan dan keberhasilan program sekolah sebelumnya. Oleh karena itu perlu bagi kepala sekolah melakukan analisis perencanaan program dengan menerapkan analisis SWOT sehingga akan terhindar dari kesalahan-kesalahan dalam penyususnan rancangan program sekolah.

Tugas kepala sekolah dalam pengorganisasian meliputi menyusun dan mengatur struktur organisasi / kepegawaian di sekolah, merinci dan menentukan tugas-tugas kepada guru dan staf, membagi kerja kedalam tugas individu atau kelompok, dan mengatur hubungan kerja (horizontal dan vertical). Oleh karena itu kepala sekolah perlu memperhatikan faktor-faktor situasional seperti kondisi struktur organisasi, kemampuan warga sekolah dan faktor lingkungan sekitarnya.

Dalam pengkoordinasian tugas yang dilaksanakan oleh kepala sekolah antara lain mengkoordinasikan tugas-tugas guru, mengkomunikasikan program-program sekolah kepada semua warga sekolah, melakukan pertemuan, diskusi atau semacamnya untuk menginformasikan gagasan dan informasi yang penting, serta untuk mengatasi masalah yang dihadapi guru.

Dalam kegiatan ini kepala sekolah juga melakukan hubungan dan kerjasama antara sekolah dengan masyarakat, dunia usaha. Atau pihak luar yang terkait untuk mengembangkan dan merealisasikan misi dan 
tujuan sekolah. Oleh karena itu sedapat mungkin kepala sekolah berupaya menciptakan lingkungan dan iklim kerja yang produktif dan kondusif. Tugas kepala sekolah lainnya yang dapat dilaksanakan dalam pengawasan dan evaluasi adalah mengendalikan semua tugas dan tanggung jawab yang di berikan kepada guru, mengawasi dan memantau kegiatan guru, menilai kinerja bawahan termasuk kinerja guru, dan menentukan kriteria penilaian dan standar kerja guru. Dengan pengawasan dan evaluasi tersebut, kepala sekolah sekaligus dapat memantau proses kerja warga sekolah sehingga akan diketahui apakah program sekolah telah dilaksanakan atau belum dan apakah hasil yang telah dicapai sesuai dengan tujuan yang ditetapkan atau tidak.

Penelitian yang relevan dengan penelitian ini adalah penelitian milik Vela Miarri Arimbi (2015) yang berjudul pengaruh kepemimpinan kepala sekolah terhadap kinerja guru sekolah menengah kejuruan (SMK) Negeri di Temanggung tahun ajaran 2011/2012. Hasil penelitiannya menunjukan bahwa kepemimpinan kepala sekolah berpengaruh secara signifikan terhadap kinerja guru SMK Negeri di Temanggung Tahun Ajaran 2011/2012. Penelitian yang dilakukan oleh Nurdin (2017), yang berjudul "Pengaruh Kepemimpinan Kepala Sekolah Terhadap Kinerja Guru Di SD Negeri 33/5Mattoangin Kabupaten Pangket”, Penelitian ini bertujuan untuk mendeskripsikan pengaruh kepemimpinan kepala sekolah terhadap kinerja guru honorer. Penelitian ini merupakan penelitian tindakan kelas dengan pendekatan kuantitatif subjek penelitian guruguru sebanyak 11 guru sebagai respoden 2 atau 18,19\% responden yang berada dalam kategori rendah, dan 8 atau $72,72 \%$ responden yang berada dalam kategori sedang, serta 1 atau 9,09\% responden yang berada dalam kategori tinggi. Hal tersebut menggambarkan bahwa kepemimpinan kepala sekolah di SD Negeri 33/5 Mattoangin berada dalam kategori yakni $72,72 \%$.

Penelitian yang dilakukan oleh Ekawati (2018) yang berjudul "Pengaruh Pemberian Kompensasi Terhadap Kinerja Guru Di SMP Negeri 2 Sungguminasi Kabupaten Gowa". Penelitian ini bertujuan untuk mendeskripsikan pemberian kompensasi terhadap kinerja guru dengan memperhatikan 33 guru sebagai sampel sebanyak 8 responden menilai pemberian kompensasi di SMP Negeri 2 Sungguminasi masih rendah dengan persentase sebesar $24 \%$ selanjutnya sebanyak 20 responden menilai pemberian kompensasi di SMP Negeri 2 Sungguminasa berada pada kategori tinggi rendah dengan persentase $15 \%$. Dengan demikian dapat disimpulkan bahwa pemberian kompensasi di SMP Negeri 2 Sungguminasi berada pada kategorisedang yakni $61 \%$.

Penelitian yang dilakukan oleh Astiti (2015) yang berjudul "Pengaruh Kepuasan Dan Motivasi Kerja Terhadap Kinerja Guru Tingkat SMA/SMK Di Kota Yogyakarta". Penelitian ini menggunakan metode Kuantitatif dan penelitian ini yang bertujuan untuk mendeskripsikan kepuasan dan motivasi kerja terhadap kinerja guru honorer. Penelitian ini bertujuan mendeskripsikan kepuasan kerja (X1) dan motivasi kerja (X2) memiliki pengaruh positif dan signifikan terhadap kinerja guru honorer (Y) di SMA/SMK Kota Yogyakarta. Sehingga dapat disimpulkan pula hipotesis ketiga diterima apabila guru dalam melakukan pekerjaan memiliki kepuasaan yang tinggi maka hal ini akan memotivasikan guru untuk melakukan pekerjaan yang optimal. Untuk mengoptimalkan guru maka dapat dilakukan dengan pemenuhan kebutuhan mempertahankan hidup kebutuhan akan rasa aman, kebutuhan sosial, kebutuhan akan penghargaan, kebutuhan prestasi, kebutuhan dalam mengektualisasikan diri di sekolah. Dengan demikian maka guru yang puas akan pekerjaannya akan mendorong guru termotivasi sehingga meningkatkan kinerja guru.

Penelitian yang dilakukan oleh Nur Muhammad Imanuddien yang berjudul "Pengaruh Motivasi Kerja Terhadap Kinerja Guru Di SMA Negeri 10 Kota RUMPUN IPS Se-Kecamatan Temanggung" berdasarkan analisis data mengenai pengaruh motivasi kerja $(X)$ dan kinerja guru $(Y)$ di SMA Rumpun Se-Kecamatan Temanggung dapat diambil kesimpulan motivasi kerja berpengaruh positif dan signifikan terhadap kinerja guru honorer. Hasil penelitian diketahui motivasi kerja menghasilkan koefisien regresi 0,381 dan tingkat signifikan sebesar $0.038<0,05$. Untuk koefisien determinasi diperoleh angka koefisien R Square sebesar 0,146 . Hal ini berarti bahwa sebesar $14,6 \%$ dapat dijelaskan oleh motivasi kerja terhadap kinerja guru sedangkan sisanya $85,4 \%$ dijelaskan oleh sebab-sebab yang lain di luar variable motivasi kerja.

Penelitian yang dilakukan oleh Yulia Racmawati, yang berjudul "Pengaruh Kepemimpinan Kepala Sekolah Terhadap Kinerja Guru Di SMK Sandikra Bekasi Jawa Barat", Penelitian ini bertujuan untuk mendeskripsikan pengaruh kepemimpinan kepala sekolah terhadap kinerja guru. Penelitian ini merupakan penelitian tindakan kelas dengan pendekatan kuantitatif subjek penelitian guru-guru sebanyak 23 guru sebagai respoden 2 atau $26,19 \%$ responden yang berada dalam kategori rendah, dan 8 atau $81,72 \%$ responden yang berada dalam kategori sedang, serta 1 atau 8,09\% responden yang berada dalam kategori tinggi. Hal tersebut menggambarkan bahwa kepemimpinan kepala sekolah di SMK Sandikra Bekasi Jawa Barat berada dalam kategori yakni 83,72\%.

\section{METODE PENELITIAN}

Penelitian ini adalah jenis penelitian kuantitatif jenis korelasional, dilaksanakan di SMP Negeri 7 Prabumulih, SMP Negeri 8 Prabumulih dan SMP Negeri 12 Prabumulih. Adapun lamanya waktu yang digunakan untuk penyusunan dan pelaksanaan pengambilan data, pengolahan data, dan pengambilan kesimpulan atau durasi keseluruhan penelitian ini membutuhkan waktu selama lima bulan. Penelitian ini 
menggunakan metode kuantitatif dengan jenis korelasional. Pada penelitian ini dikaji kekuatan hubungan kepemimpinan kepala sekolah dan manajerial kepala sekolah terhadap kinerja guru baik secara sendiri-sendiri maupun secara bersama-sama. Teknik pengumpulan data menggunakan angket dan dokumentasi. Teknik Analisis Data dilakukan dengan cara (1) Deskripsi Data, Data setiap variabel diolah dengan statistik deskriptif, (2) Pengujian Persyaratan Analisis Data, (3) Pengujian Hipotesis. Hipotesis pertama dan kedua dianalisis dengan menggunakan teknik korelasi dan regresi sederhana dengan Uji F dan Uji t. Hipotesis ketiga dianalisis dengan menggunakan teknik korelasi dan regresi ganda dengan Uji F untuk memeriksa peluang pengembangan prediksi secara kondisional menggunakan teknik korelasi parsial.

\section{HASIL DAN PEMBAHASAN}

\section{Pengaruh Kepemimpinan kepala sekolah Terhadap Kinerja Guru}

Berdasarkan hasil analisis yang telah diuraikan di atas diperoleh hasil bahwa variabel (X1) kepemimpinan kepala sekolah berpengaruh secara signifikan terhadap variabel $(Y)$ Kinerja guru di SMP Negeri Prabumulih. Berdasarkan uji t, dimana nilai thitung > dari t tabel. Dengan demikian didapatkan bahwa Ho ditolak dan Ha diterima, sehingga didapatkan bahwa kepemimpinan kepala sekolah mempunyai pengaruh yang signifikan terhadap kinerja guru. Dari hasil analisa diketahui bahwa responden sebanyak 99 dihasilkan nilai korelasi sebesar 0,98. Dari data diatas dapat diambil kesimpulan bahwa ada korelasi signifikan antara variabel kepemimpinan kepala sekolah (X1) terhadap variabel Kinerja Guru (Y). Dari hasil koefisien diterminasi maka dapat diketahui nilai r2. Nilai ini mengandung arti bahwa pengaruh kepemimpinan kepala sekolah (X1) terhadap Kinerja Guru (Y) adalah sebesar 97\% sedangkan sisanya Kinerja Guru dipengaruhi oleh variabel lain yang tidak diteliti di dalam penelitian ini. Dengan kata lain, kinerja guru dapat ditingkatkan dengan peran kepemimpinan kepala sekolah. Semakin baik peran kepemimpinan kepala sekolah, maka semakin baik pula kinerja guru.

Hal ini didukung oleh penelitian terdahulu menurut Syaroni (2007) kepemimpinan kepala sekolah berpengaruh signifikan terhadap kinerja guru. Ini berarti bahwa kepemimpinan kepala sekolah dapat mempengaruhi tinggi rendahnya kinerja seorang guru. Penting bagi seorang kepala sekolah untuk mengetahui bagaimana tipe-tipe dan pola kepemimpinan untuk meningkatkan kinerja guru.

Peningkatan kinerja guru, berdasarkan hasil penelitian, dapat dilakukan dengan meningkatkan peran seorang pemimpin dalam mengarahkan dan memotivasi, membobilisasi, bahkan membagi tugas guru sesuai tupoksi agar menghasilkan guru-guru dengan kinerja yang berkualitas, dan proses pembelajaran akan berjalan baik juga.

\section{Pengaruh Manajemen Kepala Sekolah Terhadap Kinerja Guru}

Berdasarkan hasil analisis yang telah diuraikan di atas diperoleh hasil bahwa variabel (X2) manajemen kepala sekolah berpengaruh secara signifikan terhadap variabel (Y) Kinerja guru di SMP Negeri Prabumulih. Berdasarkan nilai thitung > dari t tabel sebesar. Dengan demikian didapatkan bahwa Ho ditolak dan $\mathrm{Ha}$ diterima, sehingga didapatkan bahwa manajemen kepala sekolah mempunyai pengaruh yang signifikan terhadap kinerja guru. Dari hasil analisa diketahui bahwa responden sebanyak 99 dihasilkan nilai korelasi sebesar 0,93. Dari data diatas dapat diambil kesimpulan bahwa terdapat korelasi signifikan antara variabel manajemen kepala sekolah (X2) terhadap variabel Kinerja Guru (Y). Dari hasil analisis koefisien diterminasi maka dapat diketahui nilai r2 sebesar 0,99. Nilai ini mengandung arti bahwa pengaruh manajemen kepala sekolah (X2) terhadap Kinerja Guru (Y) adalah sebesar 99\% sedangkansisanya Kinerja Guru dipengaruhi oleh variabel lain yang tidak diteliti di dalam penelitian ini. Pada penelitian terdahulu yang telah disebutkan hasil penelitian yang menyatakan manajemen kepala sekolah adalah bagaimana kepala sekolah mampu merencanakan, melaksankan, mengawasi dan mengavaluasi kinerja guru.

Penelitian dari Syaroni (2007) dari hasil analisis data dan pembahasan, manajemen kepala sekolah berpengaruh positif dan signifikan terhadap kinerja dimana semakin manajemen kepala sekolah maka kinerja guru akan meningkat. Sebaliknya semakin rendah manajemen kepala sekolah maka kinerja guru akan menurun. Dari hasil penelitian di atas ternyata tidak ada perbedaan dengan hasil penelitian terdahulu tentang manajemen kepala sekolah. Dimana manajemen kepala sekolah memiliki keterkaitan erat dengan kinerja guru dalam melaksanakan tugas. Selanjutnya apabila dilihat dari hasil data tentang kinerja guru memperlihatkan bahwa hasil menunjukkan bahwa kinerja guru di SMP Negeri Prabumulih dipengaruhi oleh manajemen kepala sekolah.

\section{Pengaruh Kepemimpinan Kepala Sekolah dan Manajemen Kepala Sekolah Terhadap Kinerja Guru}

Berdasarkan hasil analisis yang telah diuraikan di atas diperoleh hasil bahwa variabel kepemimpinan kepala sekolah (X1) dan variabel (X2) manajemen kepala sekolah berpengaruh secara signifikan terhadap variabel (Y) Kinerja guru di SMP Negeri Prabumulih. Berdasarkan uji F, diperoleh nilai Fhitung $>$ dari F tabel sebesar 3,94. Dengan demikian didapatkan bahwa Ho ditolak dan Ha diterima, sehingga didapatkan sebuah kesimpulan bahwa "kepemimpinan kepala sekolah dan manajemen kepala sekolah secara bersama-sama 
berpengaruh terhadap kinerja guru dapat diterima dalam taraf kepercayaan 95\%. Dari temuan ini dapat diartikan bahwa faktor kepemimpinan kepala sekolah dan manajemen kepala sekolah secara bersama-sama memiliki daya prediksi yang signifikan terhadap peningkatan kinerja guru. Dengan kata lain, kinerja guru dapat ditingkatkan dengan meningkatkan kepemimpinan kepala sekolah dan manajemen kepala sekolah.

Ritme kepemimpinan kepala sekolah yang baik yang baik dan adanya manajemen kepala sekolah yang baik pula maka semakin baik kinerja guru di SMP Negeri Prabumulih. Hasil ini sesuai dengan penelitian yang dilakukan oleh Syaroni (2007) bahwa semakin tinggi kemampuan kepala sekolah dalam memimpin dan memanajemen sekolah yang dipimpinnya, maka semakin baik pula kinerja guru-guru di bawah pimpinannya.

Hasil analisis data pengujian hipotesis menunjukkan bahwa secara bersama-sama kepemimpinan kepala sekolah dan manajemen kepala sekolah, dimana ketiga hipotesis telah teruji secara empiris, berpengaruh signifikan terhadap kinerja guru. Temuan ini mendukung kerangka berfikir yang menyatakan bahwa kepemimpinan kepala sekolah dan manajemen kepala sekolah merupakan faktor penting dalam proses meningkatkan kinerja guru, sehingga mencapai kinerja guru yang maksimal.

\section{SIMPULAN}

Berdasarkan hasil penelitian dan pembahasan yang telah dilakukan pada bab IV sebelumnya maka disimpulkan secara parsial antara variabel kepemimpinan kepala sekolah memiliki pengaruh yang nyata terhadap kinerja guru di SMP Negeri Prabumulih, karena hasil analisis menunjukkan nilai thitung $>t$ tanel, dengan demikian Ho ditolak, artinya terdapat pengaruh yang signifikan antara kepemimpinan kepala sekolah terhadap kinerja guru SMP Negeri Prabumulih. Secara parsial antara variabel manajemen kepala sekolah memiliki pengaruh yang nyata terhadap kinerja guru di SMP Negeri Prabumulih, karena hasil analisis menunjukkan nilai thitung > t tanel, dengan demikian Ho ditolak, artinya terdapat pengaruh yang signifikan antara kepemimpinan kepala sekolah terhadap kinerja guru SMP Negeri Prabumulih. Secara simultan antara variabel kepemimpinan kepala sekolah dan manajemen kepala sekolah memiliki pengaruh sangat nyata terhadap kinerja guru SMP Negeri Prabumulih, karena hasil analisis menunjukkan nilai Fhitung > Ftabel, jadi HO ditolak. Dari hasil ini didapat bahwa ada pengaruh kepemimpinan kepala sekolah dan manajemen kepala sekolah secara bersama-sama terhadap kinerja guru di SMP Negeri Prabumulih.

\section{UCAPAN TERIMA KASIH}

Ucapan terima kasih diberikan kepada Kepala SMP Muhammadiyah Prabumulih dan Rektor Universitas PGRI Palembang yang telah membantu dalam penyelesaian jurnal ini. Kemudian terima kasih juga kepada teman-teman dan semua pihak yang telah membantu penulisan dan penerbitan jurnal ini.

\section{DAFTAR PUSTAKA}

Abdullah, A. (2020). Relationship the Work Culture and Training Programs Within Performance. International Journal of Progressive Sciences and Technologies (IJPSAT), 20(1).

Arimbi, N. (2012). Pengaruh Kepemimpinan Kepala Sekolah Terhadap Kinerja Guru Sekolah Menengah Kejuruan (SMK) Negeri di Temanggung.

Astiti, P. (2015) Pengaruh Kepuasan Dan Motivasi Kerja Terhadap Kinerja Guru Tingkat SMA/SMK Di Kota Yogyakarta.

Badeni, B. (2019). Factors Affecting Teachers' Stage of Concern on Evaluation System of Primary School Curriculum Innovation. International Journal Of Educational Review, 1(2), 1-11.

Berocci. (2009). Kepemimpinan dan Prilaku Organisasi. Jakarta: Balai Pustaka

Brotosedjati, S. (2002). Tuntunan Kepala Sekolah. Bandung: Alfabeta

Budianto., \& Komalasari. (2016). Kualitas Kepemimpinan. Jakarta: Radja Grafindo Persada

Ekawati, M. (2018). Pengaruh Pemberian Kompensasi Terhadap Kinerja Guru Di SMP Negeri 2 Sungguminasi Kabupaten Gowa. repositori.uin-alauddin.ac.id

Hasibuan. (1997). Pengertian Kinerja. Bandung: Alfabeta

Herlina (2018) Pengaruh Komunikasi Interpersonal dan Motivasi kerja Terhadap Kinerja Guru MTs Negeri Di kota Palembang. https://www.researchgate.net/publication/331887566

Imanuddien, N. M. (2018). Pengaruh Motivasi Kerja Terhadap Kinerja Guru Di SMA Negeri 10 Kota RUMPUN IPS Se-Kecamatan Temanggung. repository.uinjkt.ac.id

Komalasari, K., Arafat, Y., \& Mulyadi, M. (2020). Principal's Management Competencies in Improving the Quality of Education. Journal of Social Work and Science Education, 1(2), 181-193.

Mulyadi. (2002). Pengertian Kinerja. Jakarta: Balai Pustaka

Mulyasa. (2007). Pengertian Kepemimpinan. Jakarta: Rajawali Press 
Murkatik, K., Harapan, E., \& Wardiah, D. (2020). The Influence of Professional and Pedagogic Competence on Teacher's Performance. Journal of Social Work and Science Education, 1(1), 58-69.

Northouse. (2013). Pengertian Kepemimpinan Dalam Organisasi. Jakarta: Balai Pustaka

Nurdin, F. (2017). Pengaruh Kepemimpinan Kepala Sekolah Terhadap Kinerja Guru Di SD Negeri 33/5Mattoangin Kabupaten Pangket. repositori.uin-alauddin.ac.id

Nurhayati. (2012). Kepemimpinan Dan Manajemen. Bandung: Remaja Rosdakarya

Riyanto, R., Aryulina, D., \& Suwarsono, S. (2019). Identification of Students Knowledge on Local Games As a Basis to Develop Elementary School Science Textbook. International Journal Of Educational Review, 1(2), 12-18.

Robbins. (2003). Pengertian Kepemimpinan Dan Teori Kepemimpinan. Jakarta: PT Rineka Cipta

Rohma, S., Harapan, E., \& Wardiah, D. (2020). The Influence of School-Based Management and Teacher's Professionalism toward Teacher's Performance. Journal of Social Work and Science Education, 1(1), 13-23.

Sagala, S. (2009). Manajemen Dan Kepemimpinan. Bandung: Alfabeta.

Sulistiya, M. (2013). Pengaruh Kepemimpinan Kepala Sekolah Terhadap Kinerja Guru Di SMK Sandikra Bekasi Jawa Barat. neliti.com

Sumarno. (2009). Faktor Yang Mempengaruhi Kinerja. Jakarta: PT Ciputat Press

Syaroni. (2007). Pengaruh kinerja kepemimpinan dan manajemen Kepala sekolah terhadap kinerja guru Smp negeri di kabupaten brebes [tesis]. Semarang: Universitas Negeri Semarang.

Undang-Undang RI No. 22 Tahun 1999. Tentang Pelaksanaan Pemerintah Daerah

Uno, H. B., \& Lamatenggo. (2012). Kinerja Guru. Jakarta: Rajawali Pers

Wachidi, W., Rodgers, A., \& Tumanov, D. Y. (2020). Professional competence understanding level of elementary school in implementing curriculum 2013. International Journal of Educational Review, 2(1), 99-105.

Yahya, S. A. (2013). Tingkat Prestasi Kinerja. Jakarta: PT Rineka Cipta.

Zulaiha, D., Lian, B., \& Mulyadi, M. (2020). The Effect of Principal's Competence and Community Participation on the Quality of Educational Services. Journal of Social Work and Science Education, 1(1), 45-57.. 